\title{
Jurisdiction Of A Country's Air Territorry In International Law Perspective
}

\section{Yan Jefri Barus}

Sumatera University Faculty Of Law. E-mail: yanbarus@gmail.com

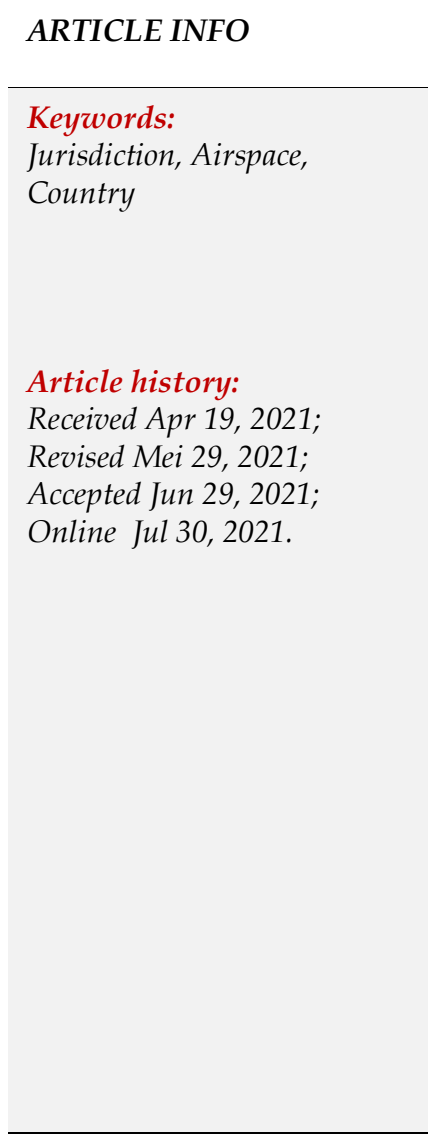

\begin{abstract}
The sovereignty of a country is no longer absolute or absolute, but at certain limits it must respect the sovereignty of other countries, which are regulated through international law. This is what became known as the relative sovereignty of the state. In the context of international law, a sovereign state must essentially obey and respect international law, as well as the sovereignty and territorial integrity of other countries. The problem in this research is How is the JURISDICTION of a country's airspace? What are the principles of air law adopted by nations in the world (internationally)? How is the JURISDICTION of a country's airspace in the perspective of international law? Its basic function is to show the way to solve research problems. The airspace contained above the land area, inland waters, and territorial sea is included in the jurisdiction of a country. This can be seen from article 1 of the Chicago Convention 1944 concerning International Civil Aviation: "State sovereignty in the air space above its territorial area is complete and exclusive sovereignity". This provision is one of the main pillars of international law governing air space. The principles of international air law include the principle of airspace sovereignty, the principle of JURISDICTION of air space, and the principle of responsibility. The principles in jurisdiction are the principle of territorial, national, passive personality, protection or security, universality, and crime according to applicable legal criteria. In relation to state jurisdiction in airspace, very closely related to law enforcement in the airspace. With jurisdiction, the country concerned has the authority and responsibility in the air to carry out law enforcement in air space.
\end{abstract}

This is an open access article under the CC BY-NC license.

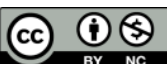

\section{Introduction}

Sovereignty is one of the elements of the existence of a country. From a scientific point of view, sovereignty can be interpreted as a supreme power over the government of the state, region, and so on. In the context of state administration, Parthiana stated that sovereignty can be interpreted as the highest power that is absolute, whole, round and cannot be divided and therefore cannot be placed under other powers. However, in the process of further development, there has been a change in the meaning of state sovereignty.

The sovereignty of a country is no longer absolute or absolute, but at certain limits it must respect the sovereignty of other countries, which are regulated through international law. This is what became known as the relative sovereignty of the state. In the context of international law, a sovereign state must essentially obey and respect international law, as well as the sovereignty and territorial integrity of other countries. 
Mochtar Kusumaatmadja said that sovereignty is an essential trait or characteristic of the state, where the state is sovereign, but has its limits, namely the space for the application of this supreme power is limited by the boundaries of the country's territory, outside its territory the state no longer has power. thus. ${ }^{4}$ In this regard, sovereignty is not seen as something that is unanimous and complete, but within certain limits already subject to restrictions in the form of international law and the sovereignty of other countries. Thus a sovereign state is still subject to international law and may not violate or harm the sovereignty of other countries. In connection with this, it can also be said that at the present time state sovereignty is the remnant of the power possessed within the limits established by international law.

Judging from the reality on the ground, recently many foreign planes have crossed the airspace of the Indonesian state. Foreign planes have passed without the permission of the control towers on the ground. Usually, most of the planes that pass without permission are military planes from foreign countries. This problem has often occurred and was negotiated with countries whose planes crossed the airspace of the Indonesian state.

The problem of management and defense in border areas is closely related to the basic conception of the state as an entity that has sovereignty, population, and territory as well as the interpretation or perception of the threats it faces. a country characterized by the protection of its sovereignty, population and territory from various types of threats. This conception is part of a total understanding of the concept of 'national security' which essentially is "the ability of the state to protect what is defined as core values, where the achievement is a continuous process, using all elements of power and resources. that exist and cover all aspects of life.

In accordance with the Chicago Convention 1944, Article I states that every country has complete and exclusive sovereignty over air space over its sovereign territory. The article provides the view that the embodiment of full and complete sovereignty over the air space above the territorial area is: (1). Every country has the right to fully and completely manage and control its national airspace (2). There is no activity or business in the national air space without obtaining prior permission or as regulated in an air agreement between a country and another country, both bilaterally and multilaterally.

\section{Method}

The existence of a series of research methods can be started from determining the type of research, where the type of research used in writing this law is normative research or also known as doctrinal research. Normative research, is a library research, so that in collecting data the authors do not need to look directly into the field, but only by collecting secondary data which is then constructed in a series of research results.

Normative research as a literature study, basically serves to show the way to solve research problems. In writing this law, normative legal research (doctrine) is descriptive, namely normative research which can be interpreted as a problem solving procedure that is studied by describing or describing the state of the object or subject being studied at the present time based on the facts that appear or as they are.

In this normative legal research, the type of data used is secondary data, namely, data collected by other people. At the time the research was started, the data was already available, or it could be referred to as given data as it was because the method of retrieval and validity were unknown.

Where secondary data in question is data that provides related information regarding the jurisdiction of the airspace of a country. In this study the authors obtained data from literature studies, in the form of literature, magazines, newspapers, papers, laws and regulations, official 
documents, correspondence, and all other secondary materials related to this research. In Normative Law research that examines secondary data, the authors here use logical, systematic, and juridical analysis techniques, to process the data that has been collected, analyzed, and concluded, in order to achieve the objectives of the research, namely to find answers to the formulation of the problem under study, so that the results of this study can be accounted for.

\section{Analysis And Results}

\subsection{Air Territory Jurisdiction Of A Country In International Law Perspective}

\section{a. Definition of State Border}

In understanding the management of state border areas as a whole, of course, an adequate understanding of what is meant by state borders is also required. At first, the border is a geographical-spatial concept. It only becomes a social concept when we talk about the people who inhabit or cross border areas. As a geographical concept, the border issue has been resolved when the two countries that have the same border area agree on the boundaries of their country's territory. The problem actually arises when the border is seen from a social perspective, because since then the conventional boundaries have melted away.

State borders are the main manifestation of a country's territorial sovereignty. The borders of a country have an important role in determining the boundaries of sovereign territory, utilizing natural resources, maintaining security and territorial integrity. The determination of national borders is in many ways determined by historical, political, national and international legal processes. In the constitution of a country, it is often stated that the determination of territorial boundaries is often stated.

State border areas can be distinguished according to their shape, namely land, sea and air borders. The following describes the meaning of each form of border.

1) Land Border. Land borders are places where points or boundary lines separate land or parts thereof into two or more different jurisdictions. So if there is a change in one party, it will cause a change in the other party, as well as their rights (joint rights/res communis).

2) Sea Border. Similar to land borders, sea borders are the location of coordinate points or boundary lines that separate waters (sea) into two or more different jurisdictions. that have been agreed internationally, such as the territorial sea, inland waters, additional zones, exclusive economic zones and the continental shelf. These legal institutions are obtained based on international conventions on the law of the sea. Such as the Geneva Conventions of 1958 and the 1982 Convention on the Law of the Sea. Although not all countries attend these conventions, many countries in the world can accept the results and use them as guidelines in determining their maritime boundaries.

3) Air Border. Air space which is part of the territory of the state is air space located above the surface of the land area and above the water area. The boundary of the airspace of a country is located at the outermost boundary of its territorial sea. , and the territorial sea. As for the outer boundary of air space which is part of the territory of the state, until now there has been no international agreement.

So far, the handling of Indonesia's border areas is felt by many to be far from adequate. In terms of affirming state boundaries (especially the sea), the sea boundaries in several Indonesian waters bordering other countries have not yet been agreed, which can cause potential problems in the future. This certainly has an impact on bilateral relations between Indonesia and countries bordering the region to be less harmonious, and the most important thing is the occurrence of violations of Indonesian territorial sovereignty. Cases such as illegal logging, shifting of territorial boundaries, smuggling, security conditions that prone to conflict, 
illegal fishing by foreign vessels are some examples of cases that occur in Indonesia's border areas.

Problems that are quite prominent and have attracted our attention recently are various violations of sovereignty over the territory of the state, unilateral claims to ownership of natural resources/islands/territories of one country by another country, various violations of human rights in border areas. (such as trafficking in person or better known as human trafficking), various criminal/criminal acts at the border (illegal logging, arm smuggling, illegal fishing), the threat of terrorism, and so on.

This fact shows that the border areas between countries are still vulnerable to various multidimensional problems. The unclear determination of boundaries between countries is one of the triggers for the emergence of these problems. for the creation of a comprehensive understanding of the importance of national border areas, especially for the creation of a conducive situation for the sovereignty and territorial integrity of a country.

With regard to borders between countries, international law makes an important contribution, especially in the implementation of negotiations and signing of border agreements or agreements between countries. International law clearly and unequivocally provides limits on the temporary use of border areas between countries, without having to affect claims by the parties. may occur, despite the fact that the parties have not yet agreed on the boundary line.

\section{b. Jurisdiction Related to Aircraft}

One consequence of the increasing volume, range and frequency of international air traffic, coupled with the increasing number of countries where logging company aircraft are registered, has led to an increase in stingy jurisdictional issues relating to crimes committed on board aircraft in flight. If this is not enough, other developments have become a major threat to the safety and confidence of international civil aviation due to the increasing incidence of hijackings and acts of terrorism against aircraft taking off.

The first significant attempt to address this issue was made by the Tokyo convention of September 14, 1963, on certain crimes and other acts committed in aircraft. The main objectives of the convention are:

1) To ensure that persons who commit crimes on board aircraft in flight, which jeopardize flight safety will not be punished simply because no State is deemed to have jurisdiction to arrest them.

2) For protection and disciplinary purposes, to grant special powers and powers, to the aircraft commander, to the crew members as well as to the passengers.

The Tokyo Convention contains detailed provisions that apply to destinations and allows aircraft commanders to lower the perpetrators and if necessary submit to the competent authorities of the countries participating in the convention. However, this provision does not apply in the air space concerned and applies to flights across the high seas in the territory of a State only : the end point of takeoff in the territory of a State which is not the country of registration, or the aircraft subsequently flies into the airspace of a State which is not the place of registration, with the perpetrator on board the aircraft. With regard to aircraft hijacking, it suffices to say that the Tokyo convention does not deal with this crime directly, but only deals with it in a limited way against hijackers, for example by allowing the hijackers to be detained or secured in the same way as against other criminals and with return of control.

\section{c. Airspace Jurisdiction Status}

1) National Airspace 
Article 1 of the 1919 Paris Convention expressly states: States parties recognize that each State has full and exclusive sovereignty over the air space above its territory. The 1944 Chicago Convention takes integrally the principles contained in the 1919 paris convention. Both conventions deliberately explain that the territory of the State also consists of its adjacent territorial sea. This is also stated by Article 2 of the Geneva Convention concerning the Territorial Sea and by Article 2 paragraph 2 of the United Nations Convention on the Law of the Sea 1982. The provisions that apply to air navigation, including air over the territorial sea, are completely different from the provisions governing shipping. maritime. In particular, there are no customary law norms that provide free passage over the territory of the State, The issue of air traffic control and security and the observation of aircraft is a very important aspect in the legal arrangements made by States. Thus, to strengthen the provisions contained in the convention, countries often make bilateral or regional agreements in the field of surveillance or security cooperation.

\section{2) International Airspace}

Territorial sovereignty of a State ceases at the outer boundaries of its territorial sea. This sovereignty does not apply to the air space over the high seas or zones where coastal States only have sovereign rights such as over the continental shelf. For security reasons, The status of freedom that prevails on the high seas cannot be absolute. Article 12 of the Chicago Convention for security reasons states that on the high seas the applicable provisions are the provisions made by ICAO in relation to the flight and maneuvers of aircraft contained in the annex of the convention.

However, internationalization is considered incomplete. First, because ICAO's regulatory power is limited to civil aviation and does not apply to public aircraft, although the ICAO assembly has suggested to States parties to include in their respective national legislation provisions which also apply to public aircraft, namely: air provisions as contained in Annex II of the Convention. ICAO does not have the implementing authority, each party is given the authority to take action so that aircraft having the nationality of that State that are above the high seas or exclusive zones conform to the provisions and regulations in force (Article 12 of the convention).

This is also stated in article 2 of the Geneva Convention on territorial seas and by article 2, paragraph 2 of the 1982 United Nations Convention on the Law of the Sea as mentioned above. The provisions that apply to air navigation, including air over the territorial sea, are completely different from the provisions governing maritime shipping. Especially there are no customary law norms that allow freely overflying over the territory of a country, which is equated with the principle of the right of innocent passage in the national waters of a country. The only exception is regarding air traffic in international straits. certain archipelagic sea lanes. Consequently, unless there is another conventional agreement.

The issue of air traffic control and security and the security of air planes is a very important aspect in the legal arrangements made by countries. Thus, to strengthen the provisions contained in the convention, countries often make bilateral or regional agreements in the field of surveillance or security cooperation. An example of this cooperation is the Convention of 13 December 1960 in which a number of European countries submitted the handling of these issues to the European Organization for the Security of Air Navigation (Eurocontrol) which was revised in 1981.

Besides that, in international air traffic there are often violations of a country's air sovereignty by civilian or military aircraft. In this case, a country whose air sovereignty is violated can ambush the foreign aircraft and be asked to land. violated cannot use countermeasures indefinitely. The actions taken must be prudent and not endanger the lives of passengers on board. This provision, which accommodates state territorial sovereignty and basic 
humanitarian considerations and must apply to everyone, is reminded and confirmed by the 1983 Montreal Protocol which contains amendments to Article 3 of the Chicago Convention and was adopted on May 10, 1984.

\section{Conclusion}

The airspace contained above the land area, inland waters, and territorial sea is included in the jurisdiction of a country. This can be seen from article 1 of the Chicago Convention 1944 concerning International Civil Aviation: "State sovereignty in the air space above its territorial area is complete and exclusive sovereignity". This provision is one of the main pillars of international law that regulates air space.

The principles of international air law include the principle of airspace sovereignty, the principle of airspace jurisdiction, and the principle of responsibility.

The principles in jurisdiction are the principle of territorial, national, passive personality, protection or security, universality, and crime according to the applicable legal criteria. In relation to state jurisdiction in airspace, it is closely related to law enforcement in the airspace. With jurisdiction, the country concerned has the authority and responsibility in the air to carry out law enforcement in air space. With regard to the authority and responsibility of the state in implementing law enforcement in air space, it cannot be separated from the content of Article 33 of the 1945 Constitution paragraph (3) which states that "earth, water and natural resources contained therein are controlled by the state and used for the greatest prosperity." people". On the basis of these provisions.

\section{References}

Anthony Csabafi, The Concept of State Jurisdiction in International Space Law, The Hague, 1971

Bambang Sunggono. Methodology Study Law. Jakarta: Raja Grafindo Persada. 1996.

Ministry of National Education, Big Indonesian Dictionary, third edition, Jakarta: Balai Pustaka, 2005.

E. Suherman., Airspace and Aerospace, Bandung: Alumni. 1978.

Fred Isjwara, Introduction to Political Science, Binacipta, Bandung 1996.

Huala Adolf, Aspects of the State in International Law, revised edition, Jakarta: Raja Grafindo Persada, 2002.

H. Bachtiar Hamzah, International Law II, Medan: USU Press, 1997.

Hans Kelsen, Principles of International Law, New York: Rinehart\& Co, 1956 page.

Huala Adolf, State Aspects in International Law, Bandung 2011 Hasnil Basri Siregar, International Organizational Law, Medan: Study Group.

Law and Society, USU Faculty of Law, 1994.

HK Martono and Amad Sudiro, Public International and National Air Law, Jakarta : Raja Grafindo Persada.

JG Starke, Introduction to International Law, London: Butterworth, 9th ed, 1984.

K. Martono, Air Law, Air Transport and Space Law, Bandung: Alumni. 2001. 
Mochtar Kusumaatmadja. Introduction to International Law, Book I General Part, Bina Cipta, Jakarta.2010.

Mufti Makarim. A, Strategy for Management and Defense of the Air Border Area of the Republic of Indonesia: Challenges in Political, Juridical and Operational Aspects, undated

Mufti Makarim. A, Strategy for Management and Defense of the Air Border Area of the Republic of Indonesia: Political, Juridical and Operational Aspect Challenges, 2011

Mirza Satria Buana, International Law Theory and Practice, Bandung: Nusamedia Publisher, 2007.

Malcolm N. Shaw, International Law, London: Butterworth, 1986.

Priyatna Abdurrasyid Introduction to Space Law and Space Treaty 1976. Jakarta: Binacipta.

Priyatna A., State Sovereignty in Air Space, Jakarta: Space Law Research Center, 1972.

Soerjono Soekanto. Introduction to Legal Research. Jakarta: UI Press. 1984. Soerjono Soekanto and Sri Mamudji. Normative Legal Research An Overview Short. Jakarta: Rajawali. 1985.

Sudargo Gautama, Indonesian International Private Law, Book I, 7th press, Jakarta:Binacipta, 1988

Suryo Magic Hadiwijoyo, Border Country In Dimension Law International, Graha Ilmu, Yogyakarta 2011.

Sri Setianingsih Suwardi, Introduction to International Organization Law, Jakarta : University of Indonesia Press.

Convention Relating to the Regulation of Aerial Navigation, signed at Paris on 13 October 1919.

Convention on International Civil Aviation, Signed at Chicago on 7 December 1944.

Convention on the Rights and Duties of States.

Charter of the United Nations and Statute of the International Court of Justice, See Robert E. Riggs, 1988; 366-387; A. Le Roy Bennet

United Nations Convention on the Law of the Sea.

Convention on Commercial Aviation,signed at hanava on 20 February 1928

Convention on the territorial sea and the contigous zone, 1983

The State of Registration of the aircarft is competent to exercise jurisdiction over offenses and acts committed onboard.

The 1993 Montevedeo Convention requires a sovereign state to have a permanent population; a defined territory; a government and capacity to enter into relations with other States.

http://www.akademik.unsri.ac.id/download/journal/files/padresources/2E\%20Makalah\%20Agreeme nt\%20International.pdf, 7 October 2013.

http:/ / beta.atjehpost.com/gaminong_read/2013/05/21/52604/15/5/Aksi-banish-foreign-airplane-inairIndonesia, accessed on October 7, 2013.

http:/ / eezcyank.blogspot.com/2011/01/law-internasional-law-air- and.html, accessed on October 1, 2013

http:/ / www.negara Hukum.com/law/ruang-air.html, accessed date 1October 2013. 